Jurnal Independent Fakultas Hukum

\title{
KETENTUAN DIVERSI TERHADAP ANAK PELAKU TINDAK PIDANA DENGAN ANCAMAN LEBIH DARI 7 (TUJUH) TAHUN PADA PUTUSAN NOMOR: 293/PID.B/2014/PN.PLG
}

\author{
Suisno, S.H.,M.Hum \\ Fakultas Hukum, Prodi Ilmu Hukum, Universitas Islam Lamongan.
}

Suisno72@gmail.com

\begin{abstract}
Abstrak
Hakim dalam amar putusan Nomor: 293/PID.B/2014/PN.PLG menyatakan terdakwa $M O B$ telah terbukti secara sah dan meyakinkan melakukan tindak pidana penganiayaan dan tanpa hak menguasai atau membawa senjata penikam atau penusuk dengan ancaman pidana 10 Tahun; Menjatuhkan pidana kepada terdakwa MOB dengan pidana penjara selama 4 (empat) bulan. Pada Putusan Nomor: 293/PID.B/2014/PN.PLG. Pasal yang didakwakan memenuhi syarat penahanan, sedangkan di sisi lain diversi wajib dilaksanakan, hal seperti ini tidak diatur lebih lanjut didalam PERMA. Namun demikian, karena diversi wajib dilaksanakan, maka dalam pemeriksaan di persidangan hakim dapat menggunakan kewenangannya untuk tidak melakukan penahanan terhadap anak.
\end{abstract}

Kata Kunci : Diversi , Hukum Pidan Anak, Perlindungan Anak.

\section{PENDAHULUAN}

Demi perlindungan terhadap anak yang bermasalah dengan hukum, proses persidangannya berada dalam pengadilan pidana anak yang berada di satu lingkup peradilan umum. Akan tetapi sebelum perkara tersebut disidangkan, semua pihak dalam hal ini penegak hukum, keluarga, masyarakat diwajibkan menyelesaikan permasalahan yang ada dapat diselesaikan di luar persidangan dan sangat diharapkan terjadinya perdamaian antara pihak terkait. Dalam hal tindak pidana yang dilakukan oleh anak di bawah umur dengan ancaman sanksi pidana di bawah 7 (tujuh) tahun dan bukan pengulangan tindak pidana dapat dilakukan upaya diversi.

Hasil yang akan dihasilkan pada proses diversi merupakan perjanjian perdamaian atar kedua belah pihak yang bisa memberikan keadilan bagi kedua belah pihak yang terlibat. Selain perdamaian, hasil diversi dapat berupa penyerahan kepada orang tua, ikut serta pendidikan dan pelatihan di lembaga pendidikan atau pelayanan sosial atau LPKS paling lama 3 (tiga) bulan. Dalam hal tidak terjadi perdamaian antar kedua belah pihak pada 
Jurnal Independent Fakultas Hukum

diversi maka proses peradilan anak akan dilanjutkan.

Hal-hal yang terdapat dalam UU SPPA seperti Diversi tidak terdapat dalam UU Pengadilan Anak yang mana dalam UU Pengadilan Anak tidak sama sekali mengedepankan penyelesaian tindak pidana yang dilakukan oleh anak di bawah umur di luar proses sidang pengadilan. Dengan kata lain pinsip keadilan restroaktif tidak diterapkan dalam UU Pengadilan Anak.

Dalam hal anak di bawah umur yang melakukan tindak pidana tidak dapat diterapkan proses diversi, maka dalam UU SPPA terhadap anak sebagai pelaku tindak pidana diterapkan sanksi pidana penjara. Sedangkan untuk penyidik, penuntut umum dan hakim yang tidak melaksanakan ketentuan yang terdapat dalam Pasal 34 dapat dikenai sanksi pidana menurut ketentuan UU SPPA.

Tujuan diversi sekali lagi difokuskan pada pemulihan keadaan anak seperti semula, bukan bertujuan untuk penghukuman terhadap anak yang melakukan tindak pidana. Sehingga akan menjauhkan pandangan masyarakat yang negatif terhadap anak dan dapat kembali dalam masyarakat guna melanjutkan kehidupannya dan diharapkan ini menjadi

1 Soerjono Soekanto, 2010, Pengantar Penelitian Hukum, Universitas Indonesia (UI) Press, Jakarta, h.6. solusi yang menjadi keadilan bagi semua pihak dan menciptakan generasi penerus bangsa yang jauh lebih baik yaitu generasi dengan mental baja yang belajar dari kesalahannya untuk lebih baik lagi demi masa depan yang terbaik untuk anak-anak Indonesia.

\section{METODE PENELITIAN}

Metode penelitian merupakan cara penelitian yang menyajikan bagaimana prosedur maupun langkah- langkah yang harus diambil dalam suatu penelitian secara sistematis dan logis sehingga dapat dipertanggungjawabkn kebenarannya secara ilmiah. Oleh karena itu, metode penelitian dapat diartikan sebagai proses prinsip- prinsip dan tata cara untuk memecahkan masalah yang dihadapi dalam melakukan penelitian. ${ }^{1}$ Untuk menganalisis permasalahan yang ada, penelitian ini menggunakan pendekatan peraturan perundang-undangan (statute approach), pendekatan kasus (case approach).

\section{HASIL PEMBAHASAN}

Pelaku tindak pidana walaupun seorang anak yang telah melakukan tindak pidana dapat disidangkan di pengadilan khusus anak yang berada di lingkungan peradilan umum, dengan proses khusus 
Jurnal Independent Fakultas Hukum

serta pejabat khusus yang memahami masalah anak, mulai dari penangkapan, penahanan, proses mengadili dan pembinaan. Sementara itu dari perspektif ilmu pemidanaan, meyakini bahwa penjatuhan pidana terhadap anak nakal (deliquency) cenderung merugikan perkembangan jiwa anak di masa mendatang. Kecenderungan merugikan ini akibat dari efek penjatuhan pidana terutama pidana penjara, yang berupa stigma (cap jahat). Dikemukakan juga oleh Barda Nawawi Arief ${ }^{2}$

Diversi merupakan pengalihan penyelesaian perkara anak dari proses peradilan pidana ke proses di luar peradilan pidana, sebagaimana disebut dalam Pasal 1 angka 7 Undang-Undang Nomor 11 Tahun 2012 tentang Sistem Peradilan Pidana Anak ("UU SPPA"). UU SPPA secara substansial telah mengatur secara tegas mengenai keadilanrestoratif dan diversi ya ng dimaksudkan untuk menghindari dan menjauhkan anak dari proses peradilan sehingga dapat menghindari stigmatisasi terhadap anak yang berhadapan dengan hukum dan diharapkan anak dapat kembali ke dalam lingkungan sosial secara wajar. Demikian antara lain yang disebut dalam bagian Penjelasan Umum UU SPPA.
Diversi secara tegas disebut dalam Pasal 5 ayat (3) bahwa dalam sistem peradilan pidana anak wajib diupayakan diversi. Pasal 8 ayat (1) UU SPPA juga telah mengatur bahwa proses diversi dilakukan melalui musyawarah dengan melibatkan anak dan orang tua/walinya, korban dan/atau orang tua/walinya, pembimbing kemasyarakatan, dan pekerja sosial profesional berdasarkan pendekatan keadilan restoratif.

Diversi ini bertujuan untuk Pasal 6 UU SPPA:

a. mencapai perdamaian antara korban dan anak;

b. menyelesaikan perkara anak di luar proses peradilan;

c. menghindarkan anak dari perampasan kemerdekaan;

d. mendorong masyarakat untuk berpartisipasi; dan

e. menanamkan rasa tanggung jawab kepada anak.

Benar bahwa pada tingkat penyidikan, penuntutan, dan pemeriksaan perkara Anak di pengadilan negeri wajib diupayakan diversi sebagaimana disebut dalam Pasal 7 ayat (1) UU SPPA. Diversi itu hanya dilakukan dilaksanakan dalam hal tindak pidana yang dilakukan Pasal 7 ayat (2) UU SPPA:

a. diancam dengan pidana penjara di bawah 7 (tujuh) tahun; dan

\footnotetext{
${ }^{2}$ Barda Nawawi Arief, Kebijakan Legislatif dalam Penanggulangan Kejahatan dengan Pidana Penjara, CV Ananta, 1994,Semarang, h.20
} 
Jurnal Independent Fakultas Hukum

b. bukan merupakan pengulangan tindak pidana.

Merujuk pada syarat diversi dan syarat penahanan terhadap anak, dapat dilihat bahwa diversi dilakukan jika tindak pidana yang dilakukan oleh si anak diancam dengan pidana penjara di bawah tujuh tahun, sedangkan penahanan hanya dapat dilakukan jika ancaman pidana penjaranya tujuh tahun atau lebih. Ini artinya, secara logika, bagi anak yang terhadapnya dilakukan diversi (ancaman pidananya di bawah 7 tahun), terhadapnya tidak mungkin ditahan dan tentu tidak boleh ditahan (penahanan hanya untuk ancaman pidana di atas 7 tahun).

Hal serupa juga dikatakan dalam sebuah tulisan, Penerapan Diversi dalam Persidangan Anak yang dibuat oleh Sofian Parerungan, 3 dijelaskan bahwa proses diversi hanya dapat dilakukan terhadap anak yang tidak ditahan karena anak yang dapat ditahan adalah yang diduga melakukan tindak pidana yang diancam dengan pidana penjara 7 (tujuh) tahun atau lebih, sedangkan proses diversi hanya diterapkan terhadap anak yang diancam dengan pidana penjara di bawah 7 (tujuh) tahun.

Sofian menambahkan, hal lainnya yang dapat saja terjadi adalah sebagaimana yang diatur di dalam Pasal 3 Peraturan
Mahkamah Agung Nomor 4 Tahun 2014 tentang Pedoman Pelaksanaan Diversi Dalam Sistem Peradilan Pidana Anak ("PERMA 4/2014"), hakim anak wajib mengupayakan diversi dalam hal anak didakwa melakukan tindak pidana yang diancam dengan pidana penjara di bawah 7 (tujuh) tahun dan didakwa pula dengan tindak pidana yang diancam dengan pidana penjara 7 (tujuh) tahun atau lebih dalam bentuk surat dakwaan subsidaritas, alternatif, kumulatif, maupun kombinasi (gabungan). apabila kita melihat, membaca dan mempelajari lebih cermat terhadap bunyi pasal tersebut diatas sudah jelas Hakim tidak dapat melakukan diversi karena bentuk dakwaan jaksa adalah tunggal.

Pada Putusan Nomor: 293/PID.B/2014/PN.PLG. Pasal yang didakwakan memenuhi syarat penahanan, sedangkan di sisi lain diversi wajib dilaksanakan, hal seperti ini tidak diatur lebih lanjut didalam PERMA. Namun demikian, karena diversi wajib dilaksanakan, maka dalam pemeriksaan di persidangan hakim dapat menggunakan

\footnotetext{
${ }^{3}$ http://pn-bangil.go.id/data/?p=207
} 
Jurnal Independent Fakultas Hukum

kewenangannya untuk tidak melakukan

penahanan terhadap anak.

\section{KESIMPULAN}

Dalam dakwaan diberikan dengan tuntutan hukuman diatas 7 (tujuh) tahun penjara, tidak dapat dilakukan upaya diversi namun apabila pandangan hakim karena faktor melihat kepentingan dan perkembangan anak yang melakukan tindak pidana, meskipun tidak sesuai dengan ketentuan diversi yang diatur dalam sistem peradilan pidana anak dapat diajukan upaya diversi. Pandangan hakim terhadap pelaku kejahatan anak yang berbeda-beda adalah dikarenakan beberapa faktor yaitu berkaitan dengan Masalah Falsafah Pemidanaan, Pedoman Pemidanaan Masalah Patokan Pidana,dan Faktor yang bersumber dari diri Hakim sendiri sehingga penerapan diversi menjadi berbeda antara hakim yang satu dengan hakim yang lainnya.

\section{DAFTAR BACAAN}

Barda Nawawi Arief, 1994, Kebijakan Legislatif dalam Penanggulangan Kejahatan dengan Pidana Penjara, CV Ananta, Semarang.

Soerjono Soekanto, 2010, Pengantar Penelitian Hukum, Universitas Indonesia (UI) Press, Jakarta.

Putusan Nomor: 293/PID.B/2014/PN.PLG http://pn-bangil.go.id/data/?p=207 